Article

\title{
Inventory of Onshore Hydrocarbon Seeps in Romania (HYSED-RO Database)
}

\author{
Artur Ionescu 1,2, Pierfrancesco Burrato ${ }^{3}$, Calin Baciu ${ }^{1, *}$, Giuseppe Etiope ${ }^{3,1}$ and \\ Boglarka-Mercedesz Kis ${ }^{2}$ \\ 1 Babes-Bolyai University, Faculty of Environmental Science and Engineering, 400294 Cluj-Napoca, Romania; \\ artur.ionescu@ubbcluj.ro (A.I.); giuseppe.etiope@ingv.it (G.E.) \\ 2 MTA-ELTE Volcanology Research Group, 1117 Budapest, Hungary; kisboglarka85@gmail.com \\ 3 Istituto Nazionale di Geofisica e Vulcanologia, 00143 Roma, Italy; pierfrancesco.burrato@ingv.it \\ * Correspondence: calin.baciu@ubbcluj.ro; Tel.: +40-744-207-597
}

Academic Editors: Carlos Alves and Jesús Martínez Frías

Received: 12 March 2017; Accepted: 23 May 2017; Published: 1 June 2017

\begin{abstract}
Seeps are the expression of the migration of hydrocarbons from subsurface accumulations to the surface in sedimentary basins. They may represent an important indication of the presence of petroleum (gas and oil) reservoirs and faults, and are a natural source of greenhouse gas (methane) and atmospheric pollutants (ethane, propane) to the atmosphere. Romania is one of the countries with the largest number of seeps in the world, due to the high petroleum potential and active tectonics. Based on a review of the available literature, and on the field surveys performed by the authors during the last 17 years, we report the first comprehensive GIS-based inventory of 470 seeps in Romania (HYSED-RO), including gas seeps (10.4\% of the total), oil seeps $(11.7 \%)$, mud volcanoes (50.4\%), gas-rich springs (12.6\%), asphalt (solid) seeps (4.3\%), unclassified manifestations $(4.0 \%)$, and uncertain seeps $(6.6 \%)$. Seeps are typically located in correspondence with major faults and vertical and fractured stratigraphic contacts associated to petroleum reservoirs (anticlines) in low heat flow areas, and their gas-geochemistry reflects that of the subsurface reservoirs. The largest and most active seeps occur in the Carpathian Foredeep, where they release thermogenic gas, and subordinately in the Transylvanian Basin, where gas is mainly microbial. HYSED-RO may represent a key reference for baseline characterization prior to subsurface petroleum extraction, for environmental studies, and atmospheric greenhouse gas emission estimates in Romania.
\end{abstract}

Keywords: hydrocarbon seeps; methane; mud volcanoes; petroleum systems; seep database

\section{Introduction}

Subsurface hydrocarbon accumulations and reservoirs in petroleum fields are not always perfectly sealed. Communication pathways may exist in many cases at faults crossing or at the boundaries of cap rocks, facilitating the upward migration of fluids from the deep reservoir to the surface. In petroleum geology, the natural release of hydrocarbon-dominant fluids is named "seepage" [1-3]. The overall geological system leading to seepage is termed "petroleum seepage system"—PSS [4], which describes the complex relationship between the elements and processes that favor the migration of hydrocarbons along faults, fractures, and highly permeable volumes of rock. Historically, seeps have provided important clues in the global exploration for oil and gas deposits. Nowadays they still can serve as indicators of gas and/or oil subsurface accumulations, acting as a natural borehole from the surface to the reservoir. However, some seeps may be related to small accumulations, without a commercial value. The assessment of the origin of seeping gas is nevertheless a key task for understanding, without drilling, the subsurface hydrocarbon potential, genesis (e.g., source rock maturity), quality (secondary alteration of gas), and other aspects related to the hydrocarbon accumulations, e.g., the presence 
of shallow microbial gas and deeper thermogenic accumulations, as well as the presence of oil, or non-hydrocarbon undesirable gases $\left(\mathrm{CO}_{2}, \mathrm{~N}_{2}, \mathrm{H}_{2} \mathrm{~S}\right.$, etc.). Seeps are indicators of tectonic discontinuities (faults) and fractured rocks. The gas released by seeps is mainly composed of methane $\left(\mathrm{CH}_{4}\right)$ and other light hydrocarbons like ethane $\left(\mathrm{C}_{2} \mathrm{H}_{6}\right)$, propane $\left(\mathrm{C}_{3} \mathrm{H}_{8}\right)$ and butane $\left(\mathrm{C}_{4} \mathrm{H}_{10}\right)$, often associated with variable amounts of $\mathrm{H}_{2} \mathrm{~S}, \mathrm{CO}_{2}, \mathrm{~N}_{2}$ and $\mathrm{He}$. Due to the explosiveness and toxic properties of hydrocarbons and $\mathrm{H}_{2} \mathrm{~S}$, respectively, some seeps can represent a geo-hazard. Invariably, they are sources of greenhouse gas $\left(\mathrm{CH}_{4}\right.$ [5-7]) and photochemical pollutants $\left(\mathrm{C}_{2} \mathrm{H}_{6}\right.$ and $\mathrm{C}_{3} \mathrm{H}_{8}$ [8]). Geothermal and volcanic $\mathrm{CO}_{2}$-rich manifestations, where the concentration of hydrocarbons is quite low (generally in the order of ppmv or less than 1-2\% by vol.), are not considered seeps [3].

Seeps, occurring on land (onshore) or on the seafloor (offshore), may appear under very different forms, as widely described in the scientific literature, including gas seeps, oil seeps, mud volcanoes, gas-rich springs, and asphalt (solid) seeps (e.g., [1,3,9]). Gas seeps release only a gaseous phase venting through outcropping rocks or soil. Oil seeps release a low proportion of gases, the expelled material being liquid. As a consequence of oil degassing and oxidation, the seep may become solid (asphalt and tar) over time. Mud volcanoes are cone-shaped structures built by the accumulation of mud expelled together with salty water and gas [9-11]. Their size may vary from meters to kilometers in diameter, and from less than one meter to hundreds of meters in height. Gas and water are typically expelled through central or peripheral craters, vents, gryphons, salses (detailed terminology and discussions are reported in a recent review by Mazzini and Etiope [11]). Gas-bearing springs are produced by ascending waters that bear significant amounts of dissolved gases, which were intercepted and taken into solution at a certain depth. When the water is supersaturated with gas, free gas and bubble plumes may form. Also in absence of bubbles, exsolution and degassing is however common at the spring outlet. Some water springs may also contain low amounts of oil, which can be observed as iridescence or drops on the water surface.

It is important to remember, then, that hydrocarbon seepage may also be "invisible", taking the form of diffuse exhalation from the ground, called "microseepage". This exhalation, not perceptible to the naked eye and detectable only by using appropriate instruments, is relatively common over petroleum fields [12].

In this work, we present a first systematic inventory of seeps in Romania, called HYSED-RO (Hydrocarbon Seeps Database in Romania), developed on the basis of literature survey and direct field investigations performed by us during the last 17 years. Romania is one of the most important European oil and gas producers [13] with 18 petroleum systems associated to the main sedimentary basins [14]. Due to intense tectonics, caused by the Carpathian orogenesis and post-orogenic basin uplift (e.g., the Transylvanian Basin), numerous hydrocarbon seepage systems developed, giving Romania one of the world's largest number of surface hydrocarbon seeps. About 1000 manifestations were documented in former works ([15] and references therein) and about 600 seeps were potentially identified more recently $[3,16]$. These seeps became part of a global onshore seep data-set, named GLOGOS [3], and successively incorporated in a wider petroleum geochemistry database [17].

HYSED-RO is an accurate revision of those first catalogues, based on field checks, removal of duplicate references to manifestations that are not real seeps, and use of the modern seep nomenclature as recently suggested by Etiope [3]. All this work resulted in a final list of 470 seeps. This is the first country-wide database for Romania, which supplies a fresh and unified view on methane seepage sites for the whole territory, providing their position as GPS coordinates, and literature references. More detailed data, including molecular and isotopic analyses for gas and water, and gas flux, are available (published and unpublished data). The database was designed to be an interface between data providers and users from different research areas: environmental sciences, geology, geochemistry, hydrocarbon exploration. HYSED-RO may represent, therefore, a crucial reference point for baseline characterization prior to subsurface petroleum extraction. The baseline characterization is important for the industry (oil companies), authorities, and local communities, for assessing the environmental impact of the petroleum production activities. We will also discuss how geologic factors controlled the 
distribution and characteristics of the seeps. We will show, in particular, the relationships between seeps, petroleum fields, tectonic structures and heat flow.

\section{History of Seep Exploration in Romania}

On the territory of Romania, surface gas manifestations were known well before the discovery of methane (the burning gas from marshes) by Alessandro Volta in 1776. The first gas manifestation was documented in Transylvania in 1671 near Bazna, where an "everlasting fire" was observed by local shepherds [18]. Scholars of the 17th and 18th centuries successively wrote about gas manifestations in Transylvania in local newspapers, poems and scientific reports. The first notice on the gas seep from Bazna is from the diary of Johann Irthell, who visited Bazna on the 11th of April 1672 to see personally the "burning waters". The news spread rapidly in Transylvania, so that after a few years the mentioned phenomenon was described in a poem of Valentin Frank von Frankenstein, while the first scientific description was given by Georgius Vette and Henric Vollgnad in 1688, in the work De aquis ardendibus [19].

The first detailed scientific report was written by Luigi Fernando Marsigli in 1727, who described and mapped the local geology of the Bazna seep, outlining the burning gas $[18,19]$. Early scientific reports on Transylvanian gas manifestations were written in the mid/late-19th century, mainly regarding the area of Sibiu [20-23]. In the 20th century many gas manifestations became known in the Transylvanian region, and they were described as mud volcanoes, eternal flames, "bubbling pools" and oils seeps. Posewitz [24] catalogued the oil-, and bitumen manifestations in Transylvania, mentioning also some eternal fires, and gas-bearing springs.

In the Moldavian region, some gas manifestations were documented in the first decade of the 20th century $[25,26]$. In his PhD thesis, Vancea [27] described in detail the distribution of seeps in the Transylvanian Plain and, as supplementary material, he described a few seeps in Romania, and the importance of connate water in petroleum exploration [28]. Banyai [29] described the morphological features of some mud volcanoes from the Eastern Transylvanian region, indicating the areas where these features are more frequent. In the following decades, seeps were mentioned in geological works [30,31]. The first catalogue of gas and petroleum manifestations in Romania, containing about 1000 seeping sites was produced as an unpublished report by Tonescu, in 1953 [15]. In this catalogue, $73 \%$ of seeps were indicated as "oil springs", and the rest of $27 \%$ were gas emanations including mud volcanoes. Unfortunately, it seems that the original report is no longer retrievable. Paraschiv [15] recalled however the seeps distribution based on Tonescu's inventory, and provided a synthesis map (Figure 1). Peaha [32] developed the first catalogue of Romanian mud volcanoes, including a set of chemical analyses of water and gas. Chromatographic analyses of a few Carpathian seeps were then included in a remarkable collection of natural gas data, mostly referring to reservoirs, by Filipescu and Huma [33].

A new approach based on gas flux measurements in seeping areas, combined with molecular and isotopic analyses has developed gradually after the year 2000 [34-36]. The first isotopic composition of methane from a Romanian seep was published in 2008 [37]. Geochemical and flux data were then reported for seeps from Transylvania [38-40], from the Carpathian Foredeep [41], and from the Moldavian Platform [40,42]. Rowland et al. [43] investigated a large number of springs in the Pannonian region, and measured the dissolved hydrocarbon concentrations, and also the $\delta^{13} \mathrm{C}^{-} \mathrm{CH}_{4}$ in some samples. A more complete survey of the geochemistry of Romanian seeps was published by Baciu et al. [44]. 


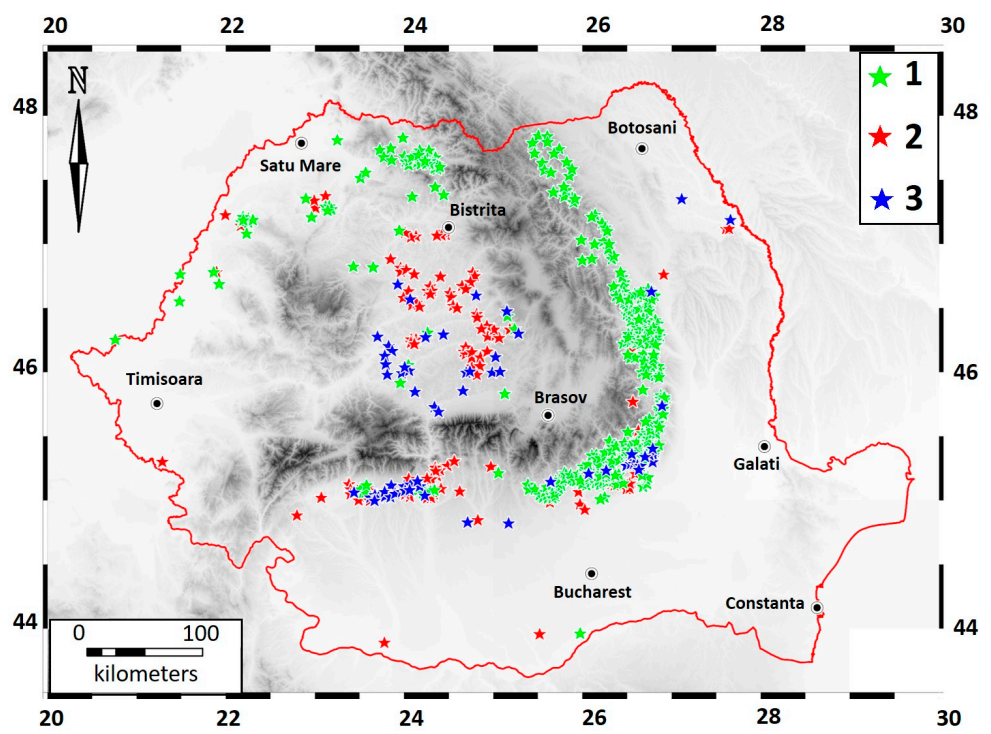

Figure 1. Distribution of the seeps inventoried by Tonescu, in 1953. 1: oil seeps (oil springs in the original catalogue); 2: gas seeps; 3: mud volcanoes (redrawn from [15]).

\section{Development of the HYSED-RO Database}

HYSED-RO developed from an accurate and wide literature survey and direct field investigations. It contains only emissions from sedimentary hydrocarbon-prone areas, respecting the proper sense of "petroleum seep" notion. $\mathrm{CO}_{2}$-rich manifestations related to geothermal or volcanic areas will be included in a separate database, although they may contain certain amounts of hydrocarbons.

The version presented in this paper (HYSED-RO v. 1.0, 2017) reports 470 seeps, out of which 98 are active, 23 are inactive (extinct) and the activity of the remaining 349 is unknown, as explained below. The database will be progressively updated as new field observations will be acquired. HYSED-RO is a GIS-based database, and as such it can be examined on the basis of geological, geo-structural and seismic maps. This allows the assessment of relationships between seepage and a wide set of geological factors, like tectonic lineaments, petroleum field locations, and heat flow (relationships described in more detail in this paper).

Field work, including identification and description of several seepage sites, was conducted to check the information reported in the literature and also to look for new, undocumented seeps. In some cases, seeps are ephemeral features, and seeps that were reported as active in the past may not show any activity today, or cannot be even identified in the field. Based on the activity of the seeps we categorize them as "active", "inactive" and "with unknown activity". Active seeps are defined as those that were mentioned in the recent literature as being active, or those that periodically are active due to different factors (rainfall, increase of pressure in the subsurface, or seismicity), or their activity has been directly observed in the field. Inactive seeps are those that had no visible activity during the last decades or are mentioned as "fossil" or "extinct seeps" in the literature. The manifestations that were mentioned in the literature only in very generic terms, that we could not identify in the field, and it is not sure whether they are real seeps or not, are classified as "uncertain". When reliable information on the existence of a seep is available, but the type of seep is not clear (gas seep, mud volcano, etc.) it is categorized as "unclassified manifestation".

The database has a simple tabular structure (Table 1), and it is divided in two sections. The first section includes data related to the type and geographic location of the seeps. Each column or field of the data table contains an attribute. Each row or record uniquely corresponds to a seepage site. Each field representing an attribute is treated as one variable, which can be defined as: "Char (n)": a text string of $n$ characters, or "Decimal (n, $\mathrm{m}$ )": a real number of $n$ digits (including decimal separator) and $m$ decimal places. 
Table 1. Structure of the HYSED-RO database.

\begin{tabular}{|c|c|c|c|}
\hline No. & Field & Variable & Description \\
\hline \multicolumn{4}{|c|}{ Section 1 (publicly available) } \\
\hline 1 & ID & Char (n) & Identification number for each individual seep. \\
\hline 2 & Name & Char (n) & The name of the seep or the name of the nearest settlement. \\
\hline 3 & Province & Char (n) & Refers to one of the seven geologic provinces defined by the USGS that cover Romania (Figure 2) [45]. \\
\hline 4 & Type & Char (n) & $\begin{array}{l}\text { Refers to the type of manifestation: gas seep, mud volcanoes, oil seep, hydrocarbon-bearing spring } \\
\text { (water seep), solid seeps (asphalt), unclassified manifestation and uncertain seeps. }\end{array}$ \\
\hline 5 & Status & Char (n) & Refers to the activity of the seep: active, inactive or unknown activity. \\
\hline 6 & Latitude & $\operatorname{Dec}(n, m)$ & GPS location, in decimal degrees. \\
\hline 8 & Reference & Char (n) & The source of information: author(s) and year \\
\hline \multicolumn{4}{|c|}{ Section 2 (available on request) } \\
\hline 9 & Area & $\operatorname{Dec}(n, m)$ & Investigated area $\left(\mathrm{m}^{2}\right)$ \\
\hline 10 & Flux & $\operatorname{Dec}(n, m)$ & $\mathrm{CH}_{4}, \mathrm{CO}_{2}\left(\mathrm{~g} \mathrm{~m}^{-2} \mathrm{~d}^{-1}\right)$ \\
\hline 11 & Molecular (gas) & $\operatorname{Char}(\mathrm{n}) \operatorname{Dec}(\mathrm{n}, \mathrm{m})$ & Molecular analysis of gas \\
\hline 12 & Isotopes (gas) & Char (n) Dec (n, m) & Isotopic analysis of gas \\
\hline 13 & Chemical (water) & Char $(n) \operatorname{Dec}(n, m)$ & Chemical analysis of water (physico-chemical properties, major ions, metals, etc.) \\
\hline 14 & Isotopes (water) & Char (n) Dec (n, m) & Isotopic analysis of water $\left(\delta^{2} \mathrm{H}, \delta^{18} \mathrm{O}, \delta^{13} \mathrm{C}\right.$-DIC) \\
\hline 15 & Others & Char (n) Dec (n, m) & Minor gases, special features, etc. \\
\hline
\end{tabular}

Char (n): text string of $n$ characters; Dec $(\mathrm{n}, \mathrm{m})$ : a real number of $n$ digits (including decimal separator) and $m$ decimal places. 
For the most representative sites, this information is complemented by gas flux estimates resulted from direct measurements, and geochemical data, including gas and water molecular and isotopic analyses, included in Section 2 of the database. When unpublished, this kind of data can be delivered to interested entities or researchers on request.

Items (1) to (8) are available for all seeps. If one item is missing, the entry in the database is not valid. The ID (identification number) is a unique code given to each individual seep in the database, and it is composed of 11 characters, in the following format:

$$
\text { CC - PPPP - TTT - \#\#\# }
$$

where CC is a two-character ISO 3166-1 code for names of officially recognized countries (https://www.iso.org/iso-3166-country-codes.html). PPPP is the code of the geologic provinces defined by the USGS [45] that cover the territory of the country: 4061-Carpathian-Balkanian Basin; 4048-Pannonian Basin; 4057-Transylvania; 1013-Ukrainian Shield; 4064—West Black Sea Basin; 4047-North Carpathian Basin; 4063-Dobrogean Orogen; 1103-Dobrogea Foreland. TTT is the type of manifestation: gas seep-GAS; mud volcano-MVO; oil seep-OIL; and gas-bearing spring-SPR. \#\#\# is an alphanumerical character ranging from 001 to 999.

\section{Data Gathering}

Published literature has been used as primary information source for identifying the seeps in the field. Together with the literature data, any other information from newspapers, TV, internet, oral communications, etc. regarding the potential existence of seeps, has been considered. The general geological structure was also an important premise in the assessment of the potential seeping areas. The geographic coordinates of each seep were determined by a GPS handheld device. Coordinates of the closest locality have been considered for the uncertain sites that were not identified in the field. Very often, more vents may occur on a limited area, suggesting they belong to a unique seepage system. In some cases, this is very intuitive, as in the case of Paclele Mari, where dozens of vents occur on a convex plateau, and the whole structure can be defined as one mud volcano, considering there is a unique channel that feed all the vents.

\section{Seep Distribution and Mapping}

The majority of the seeps are mud volcanoes (50.4\%), followed by gas-bearing springs $(12.6 \%)$, oil seeps $(11.7 \%)$, gas seeps $(10.4 \%)$, and solid seeps $(4.3 \%)$. The percentage of unclassified manifestations is $4.0 \%$, and $6.6 \%$ of the seeps are uncertain (Table 2).

Table 2. Statistics of the HYSED-RO database.

\begin{tabular}{|c|c|c|c|c|}
\hline Type & Active & Inactive & Unknown Activity & Total \\
\hline Mud volcano & 64 & 21 & 152 & 237 \\
\hline Gas & 13 & 2 & 34 & 49 \\
\hline Spring & 17 & 0 & 42 & 59 \\
\hline Oil seep & 4 & 0 & 51 & 55 \\
\hline Solid seep & 0 & 0 & 20 & 20 \\
\hline $\begin{array}{l}\text { Unclassified } \\
\text { manifestation }\end{array}$ & 0 & 0 & 19 & 19 \\
\hline Uncertain & 0 & 0 & 31 & 31 \\
\hline Total & 98 & 27 & 349 & 470 \\
\hline
\end{tabular}

The distribution of seeps is in agreement with the occurrence of petroleum plays, and depends on the tectonic features of the areas of interest. In order to better understand the distribution of the seeps, HYSED-RO was implemented in a GIS interface, using MapInfo Professional V. 11 (Pitney Bowes Software, Troy, NY, USA). The layers used in the evaluation of the seep occurrences are: the geological map of Romania 1:1,000,000 [45], a Digital Elevation Model (DEM) of Romania, the map of the geologic 
provinces in Romania [46] (Figures 2 and 3), and the geothermal map of Romania [47]. The maps were digitized and geo-referenced in WGS84 Latitude and Longitude projection. The seeps have been categorized according to their type and status. Their geographic coordinates and features have then been stored in a GIS environment, able to manage and analyze all geographical data. In particular, the following base layers are included: tectonics [48,49]; geological provinces of Europe [46]; heat flow $[47,50-52]$.

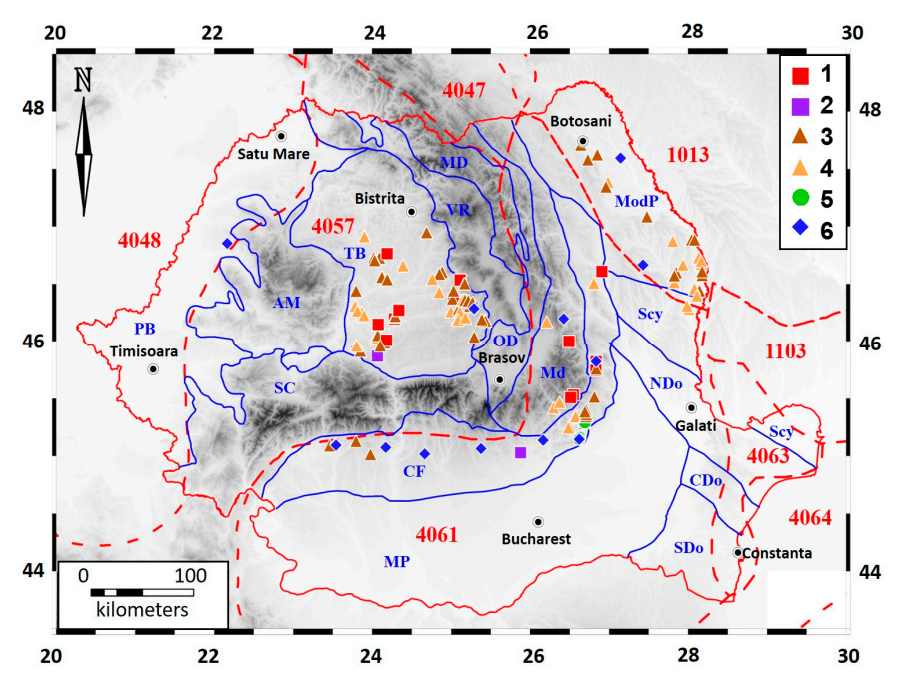

Figure 2. Distribution of the active and inactive seeps included in the HYSED-RO database in relation to the geologic provinces defined by the USGS (red dashed lines and numbers [45], and with the main structural units of Romania (blue lines and acronyms) [48]. 1013: Ukrainian Shield; 1103: Dobrogea Foreland; 4047: North Carpathian Basin; 4048: Pannonian Basin; 4057: Transylvania; 4061: Carpathian-Balkanian Basin; 4063: Dobrogea Orogen; 4064: Western Black Sea Basin; PB: Pannonian Basin; TB: Transylvanian Basin; AM: Apuseni Mountains; SC: Southern Carpathians; VR: Volcanic Range, MD: Median Dacides; OD: Outer Dacides; Md: Moldavides; ModP: Moldavian Platform; Scy: Scythian Platform; NDo: North Dobrogea; CDo: Central Dobrogea; SDo: South Dobrogea; MP: Moesian Platform; 1: active gas seep; 2: inactive gas seep; 3: active mud volcano; 4: inactive mud volcano; 5: active oil seep; 6 : active hydrocarbon bearing spring.

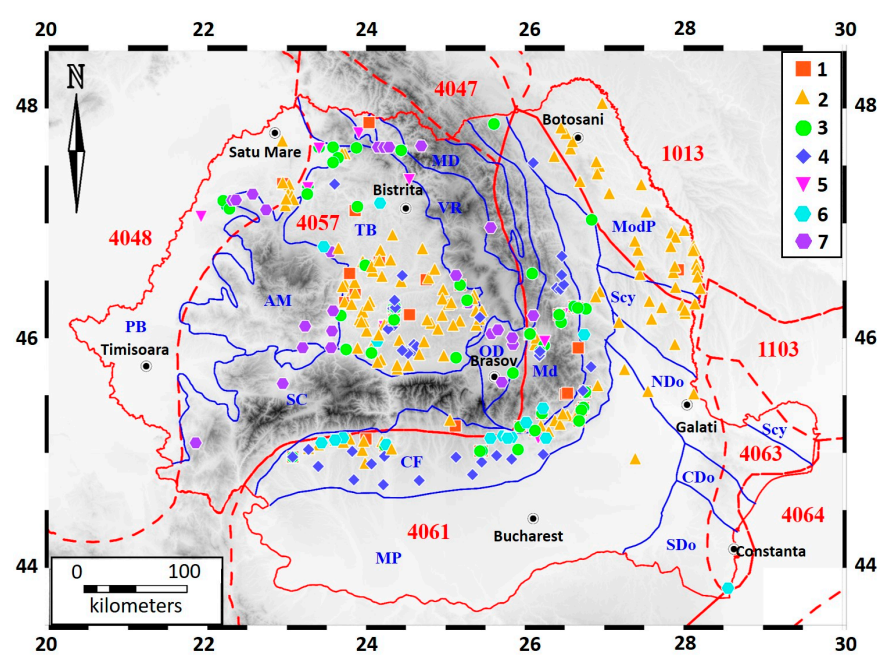

Figure 3. Distribution of the seeps with unknown activity and uncertain seeps in relation to the geologic provinces [47]. 1: gas seep; 2: mud volcano; 3: oil seep; 4: hydrocarbon bearing spring; 5: solid seep; 6: unclassified manifestation; 7 : uncertain manifestation. 


\section{Relationship between Seepage and Geological Factors}

\subsection{Seeps vs. Tectonics}

A close link has been observed between the occurrence of seeps and the tectonic characteristics. The mud volcanoes, in particular, are sensitive indicators of the stress field in folded areas. The anticlinal crests in hydrocarbon-prone areas meet favorable conditions for the appearance of migration pathways for the fluids. Conduits may take the form of pipes or dikes, reflected at the surface by the shape and distribution of the mud-releasing features [53].

Seeps are usually located along tectonic lineaments, as illustrated by several cases in the Transylvanian Basin and in the Eastern Carpathian Flysch and Foredeep zones (Figures 4 and 5). In the inner part of the Transylvanian Basin, the main structural elements are the gas-bearing domes and anticlines. Mud volcanoes and dry seeps may occur on these gas-bearing structures, presumably controlled by the presence of local faults (e.g., Deleni, Tauni, Bazna seeps). On the south-western border of the basin, a large number of seeps are located along the sinuous Rusi-Cenade reverse fault system, cutting Pliocene deposits (Figure 6). Faults associated to the numerous salt diapirs, located along the borders of the basin, provide pathways for the upward migration of gas (e.g., Praid and Homorod seeps—eastern border, Ocna Sibiului—southern border, Ocnisoara—western border).

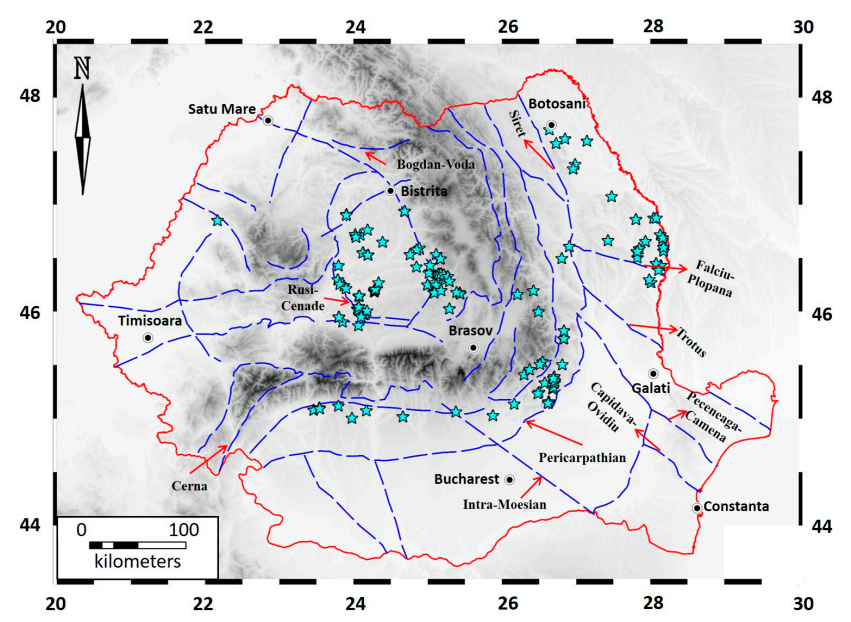

Figure 4. Distribution of active and inactive seeps included in the HYSED-RO database in relation to major faults (blue dashed lines). Tectonics after [48,49,54].

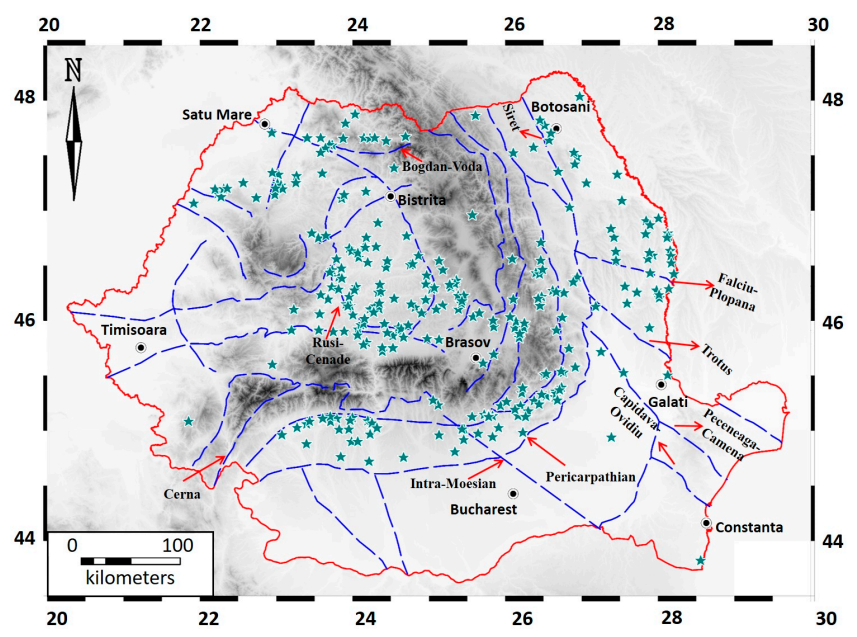

Figure 5. Distribution of uncertain seeps in relation to major faults (blue dashed lines). Tectonics after $[48,49,54]$. 


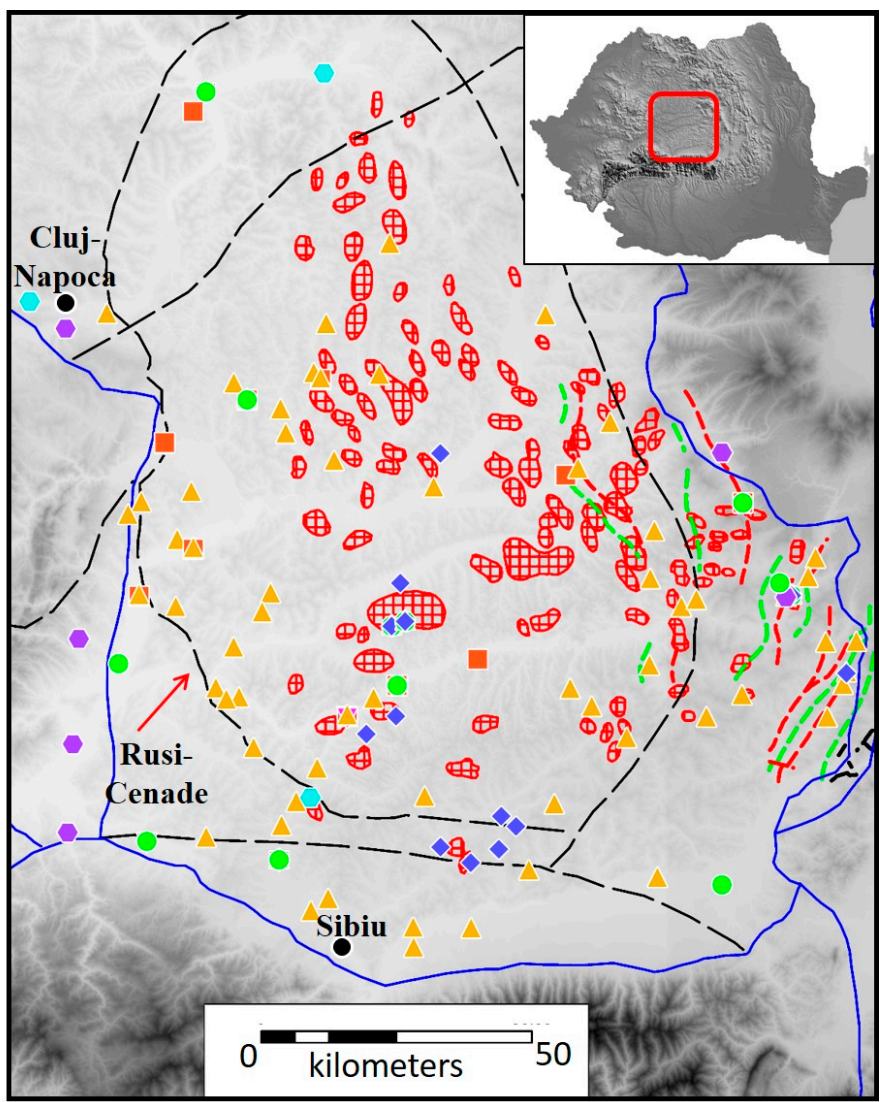

Figure 6. Distribution of seeps in the Transylvanian Basin in relation to the gas commercial deposits (red pattern), major faults (black dashed lines), anticlines (red dashed lines), synclines (green dashed lines), after [38,54]. Symbols of the seeps are the same as in Figure 2.

In the Eastern Carpathian Flysch and Foredeep, the main tectonic features are represented by $\mathrm{N}-\mathrm{S}$ trending anticlines and synclines and related thrust and reverse faults. Consequently, the seeps are located on lineaments following the same direction. A relevant example is the Berca-Arbanasi hydrocarbon-bearing structure (Figure 7), where the largest Romanian mud volcanoes are located [35]. Four mud volcanoes (from North to South: Beciu, Paclele Mici, Paclele Mari and Fierbatori) are positioned on the axis of the faulted anticline, generally at the intersection with transversal faults. Paroxistic activity of the mud volcanoes has been observed in relation to the important seismic events in the nearby Vrancea seismic area [55].

The strata in the flysch zone are strongly folded and tilted. Figure 8 depicts the main features and tectonic style along a WNW-ESE section through the most external flysch units and the western margin of the Foredeep [56], relevant for the gas seeps of Lepsa (about $8 \mathrm{~km}$ north of the section) and Andreiasu (about $15 \mathrm{~km}$ south of the section). Lepsa seep is located on a north-south oriented overthrust fold in the Paleogene flysch, dominated by a succession of thin layers of sandstone and clay. At Andreiasu, close to the Casin-Bisoca Fault, the strata are in a sub-vertical position and faulted, thus facilitating the gas migration through the Miocene sandstones and volcanic tuffs occurring in the area.

Although the Neogene of the Moldavian Platform (Romanian segment of the East European Platform) shows some potential of gas generation, there are few commercial deposits due to the lack of proper traps and reservoirs [15]. In most of the cases, a few seeps are found on river terraces or close to the river bed and probably related to shallow gas accumulations. The monocline structure of the Neogene sediments is intersected by the erosion along the valleys, thus providing connections to the surface of the shallow gas accumulations [42]. 


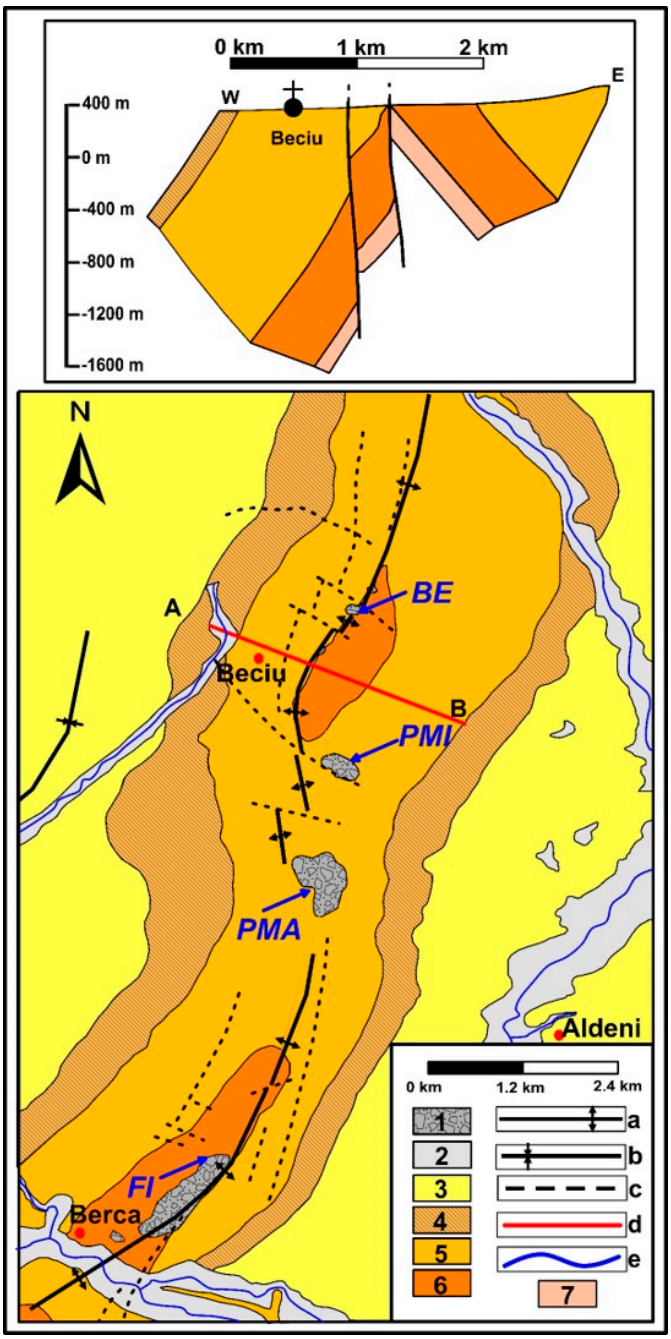

Figure 7. Geological map and cross-section A-B on the Berca-Arbanasi hydrocarbon-bearing structure, showing the position of the mud volcanoes in relation to tectonic structures. 1: mud volcanoes; 2: alluvial sediments; 3: Romanian; 4: Dacian; 5: Pontian; 6: Meotian; 7: middle Miocene; a: anticline; b: syncline; c: fault; d: transect; e: river; BE: Beciu; PMI: Paclele Mici; PMA: Paclele Mari; FI: Fierbatori (modified after [30]).

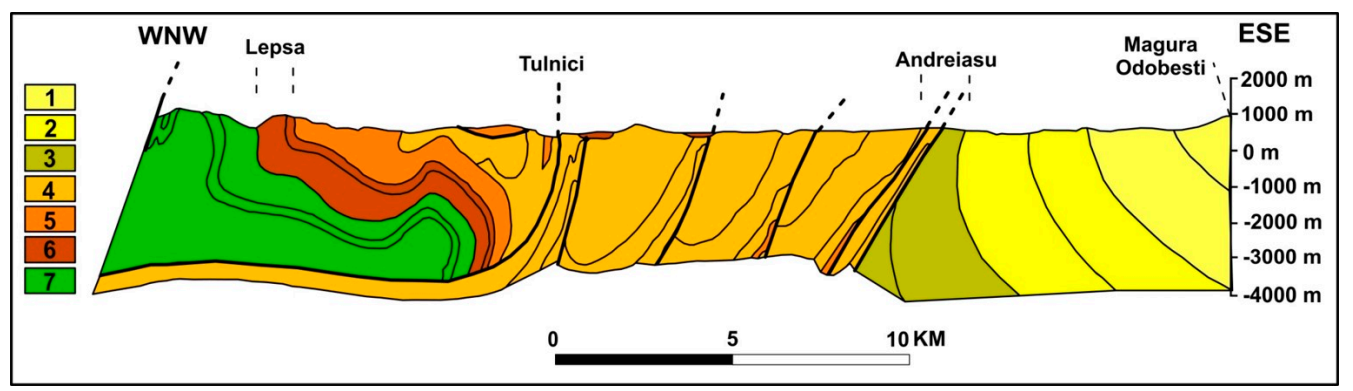

Figure 8. Cross-section at the limit between the Eastern Carpathian flysch units and the Foredeep, showing the structural style for Lepsa and Andreiasu seeps. 1: Upper Pliocene (sands, sandstones, clays); 2: Lower Pliocene (sands, sandstones, clays); 3: Upper Miocene (marls, sandstones, volcanic tuffs); 4: Lower Miocene (sandstones, marls, evaporites); 5: Oligocene (menilites, dysodiles, sandstones); 6: Paleocene-Eocene (sandstones, clays, marls); 7: Cretaceous (conglomerates, marls, limestones) (modified after [56]). 


\subsection{Seeps vs. Petroleum Systems}

Approximately $30 \%$ of the Romanian territory is covered by 18 petroleum systems that range from Palaeozoic to Pliocene in age [14]. We observed that most of the seeps are located in correspondence with productive reservoirs of these petroleum systems [44]. The inventory mapping also shows that the type of seepage reflects the characteristics and source rock maturity of the petroleum systems. Microbial gas seeps (whose geochemical data are described in [44]) dominate the low temperature diagenetic system of the Transylvanian Basin, included in the USGS geologic province denomination 4057 (Figure 3). Thermogenic gas seeps $([44,57])$ are widespread in the catagenetic systems of Carpathian, Moesian and Moldavian geologic units belonging to the provinces 4061 and 1013.

Liquid (oil) and solid (asphalt) seeps are obviously located in correspondence with thermogenic petroleum systems (Eastern Carpathians, Apuseni Mountains and NW of the Transylvanian Basin) where source rock maturity entered the oil window.

Overall, seep type and geochemistry reflect the different geological and maturity conditions of the basins where seeps are located. A vertical sequence for petroleum systems has also been suggested in some basins by seeps displaying different maturity and secondary alterations ([44]). Accordingly, the seeps can be used as exploration tool to assess the subsurface petroleum potential and quality.

\subsection{Seep vs. Heat Flow}

Heat flow determines the temperatures at depth that, together with the duration of the thermal event, influence the maturity of source rocks and the consequent gas and oil production in sedimentary basins. Too high temperatures $\left(>250^{\circ} \mathrm{C}\right.$, at metagenesis after catagenesis [58]), destroy hydrocarbons. Heat flow data of Romania ([47] and references therein) have been compared with the location and type of seeps. All the investigated seeps are located in low and medium heat flow areas (Figure 9), consistent with typical thermal gradients of sedimentary petroleum provinces [58,59]. The central part of the Transylvanian Basin is a low heat flux region, the values increasing towards the borders, from 30 to $60-70 \mathrm{~mW} \mathrm{~m}^{-2}$, more accentuated on the eastern side of the basin close to the volcanic range of the Eastern Carpathians [47]. The relatively cold and thick pile of sediments of the Transylvanian Basin has produced microbial methane. Higher temperatures, approaching catagenesis and oil window, may justify thermogenic gas seeps at the western border of the Transylvanian Basin [44]. The heat flow further increases towards the volcanic areas of the Eastern Carpathians, exceeding $120 \mathrm{~mW} \mathrm{~m}^{-2}$, in the northern part and at the southern border of the volcanic range. Here there are no documented seeps anymore (Figure 9) and geothermal, $\mathrm{CO}_{2}$-rich manifestations prevail [60]. Some of the uncertain seeps described in the old literature, however, occur within the higher thermal flux zones (Figure 10), as the northern and southern segments of the Eastern Carpathians. Such cases deserve specific investigation because at least some of the "presumed" seeps, may be actually manifestations of geothermal $\mathrm{CO}_{2}$-rich fluids.

The current heat flow in the Carpathian Flysch and Foredeep areas is around $40-60 \mathrm{~mW} \mathrm{~m}^{-2}$, with some exceptions at the limit between the Southern Carpathian Foredeep and the Moesian Platform, where it may drop down to $20-30 \mathrm{~mW} \mathrm{~m}^{-2}$. In the Moldavian Platform the heat flow is about 40-50 $\mathrm{mW} \mathrm{m}^{-2}$, with a slight increasing tendency from West to East [47]. 


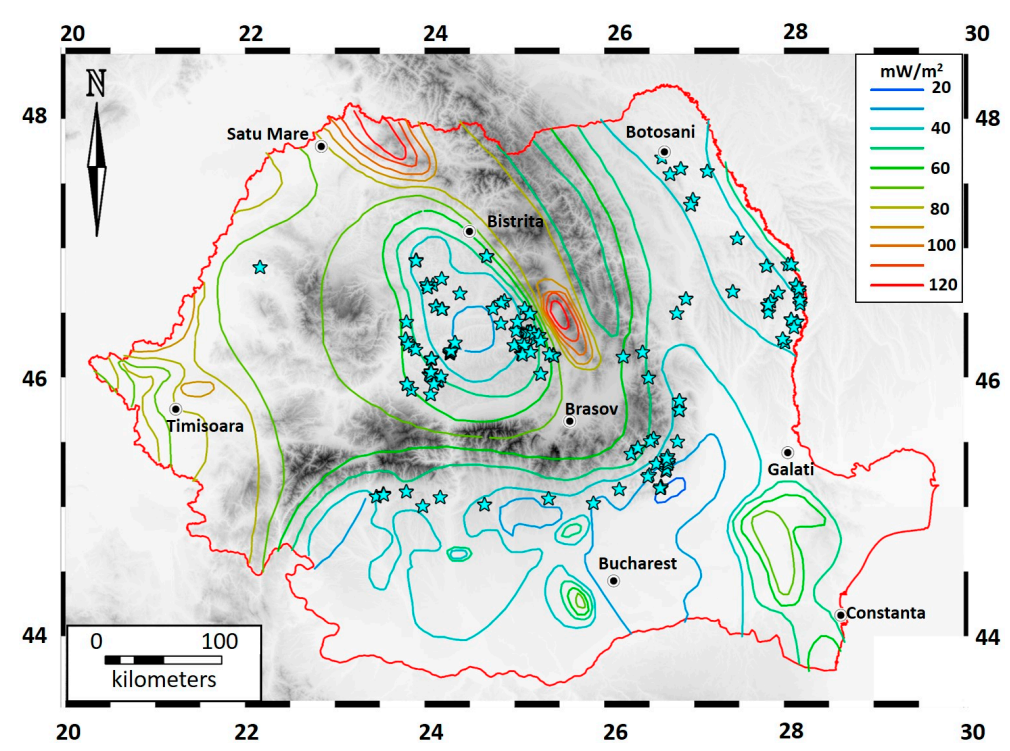

Figure 9. Distribution of active and inactive seeps of the HYSED-RO database in relation to the heat flow (modified after [47,50-52]).

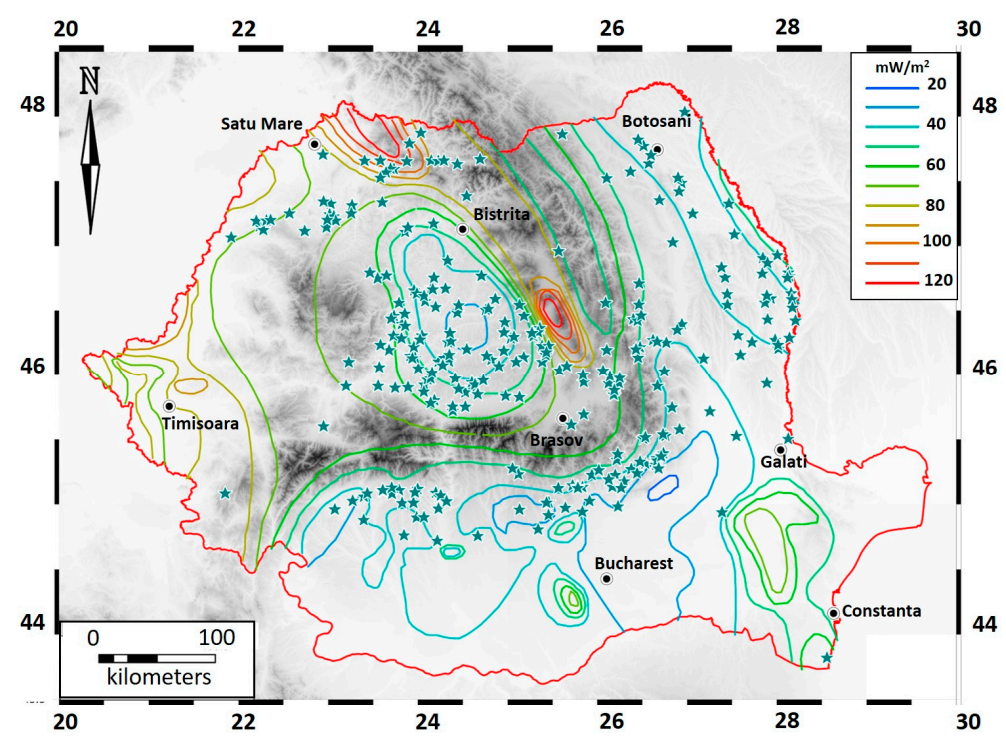

Figure 10. Distribution of seeps with unknown activity and uncertain seeps in relation to the heat flow (references as in Figure 9).

\subsection{Gas Origin and Output to the Atmosphere}

HYSED-RO contains molecular and isotopic data of the natural gas released by 17 major seeps and methane flux data from almost 100 seeps distributed in the several petroleum basins of Romania. Detailed discussion on gas origin and emission to the atmosphere is reported in Baciu et al. [44]. Here we report key concepts that explain the main meaning of the geochemical data of the various seeps reported in the inventory.

Stable $\mathrm{C}$ and $\mathrm{H}$ isotope composition of methane (coupled with molecular hydrocarbon composition and other geological data) revealed that seeps in the external area of the Carpathians (in the Flysch and Foredeep zones) and on the western margin of the Moldavian Platform, release gas with thermogenic origin. In some cases the gas shows signals of secondary methanogenesis after biodegradation [44]. The gases from the Transylvanian Basin are mainly microbial; however, 
thermogenic gas occurs at the eastern edge of the basin, close to the Neogene volcanic belt. In the central part of the Transylvanian Basin the gases contain measurable amounts of $\mathrm{C}_{2+}$ alkanes, which may imply that the gas is not totally microbial [44].

The comparison of reservoir vs. seep geochemistry $\left(\mathrm{CH}_{4}\right.$ isotopes and molecular composition) confirms that most seeps are actually linked to reservoirs. For intense, high flux seeps, the gas has also the same hydrocarbon molecular composition of the reservoir (same $C_{1} / C_{2+}$ ratio) [44]. In general, gas seep geochemistry reflects the different geological and maturity conditions of the basins where the seeps are located, and highlights that in the same basin, different gas sources with different maturity and secondary alterations may exist. This may be due to source rocks or reservoirs at different depths, suggesting a vertical sequence of petroleum systems.

HYSED-RO flux data show that the mud volcanoes on the Berca-Arbanasi hydrocarbon-bearing structure and the Sarmasel and Tauni seeps in Transylvania are the biggest gas emitters, with an estimated output in the order of hundreds of tons of methane per year. Total estimated methane emission from seeps in Romania is around $3000 \mathrm{t} \mathrm{y}^{-1}$ [44].

Available data of the stable $\mathrm{C}$ composition of methane can be used in top-down atmospheric models for the estimation of atmospheric methane emissions [61]. The average $\delta^{13} \mathrm{C}_{-} \mathrm{CH}_{4}$ value for the Carpathian Foredeep is - $41.1 \%$ (Alimpesti, Andreiasu, Bacau, Lopatari, Raiuti, Paclele mud volcanoes), while for the central-western Transylvanian Basin is $-64.6 \%$ (Sarmasel, Deleni, Tauni seeps), and for the eastern Transylvanian Basin is $-30.9 \%$ (Praid, Corund, Homorod seeps). Considering the relative $\mathrm{CH}_{4}$ emission factors of the several seeps, whereby Carpathian Foredeep seeps are the most intense and large [44], a weighted $\delta^{13} \mathrm{C}-\mathrm{CH}_{4}$ value of about $-44 \%$ is estimated.

\section{Concluding Remarks}

The present paper describes the first comprehensive GIS-based inventory of hydrocarbon seeps in Romania (HYSED-RO), based on (a) investigations performed in the field by the authors during the last 17 years and (b) information gathered in the literature covering more than three centuries. The database currently comprises a total number of 470 seeps, out of which 98 are active, 23 are inactive, and the activity of 349 is unknown. Most of the seeps are mud volcanoes (50.4\%). In the other categories, there are gas-bearing springs $(12.6 \%)$, oil seeps $(11.7 \%)$, gas seeps $(10.4 \%)$, solid seeps $(4.3 \%)$, unclassified manifestations $(4.0 \%)$, and uncertain seeps $(6.6 \%)$.

The occurrence of the seeps is largely dependent on the spatial distribution of the hydrocarbon bearing structures and on the regional and local tectonics (faults and vertical, fractured stratigraphic contacts), which determine communication pathways for the fluids from the reservoirs to the surface. HYSED-RO shows, in particular, that the most important gas emitting structures are distributed over commercial reservoirs in the Carpathian Foredeep and Transylvanian Basin. Geochemical studies of the several seeps [44] showed that the emitted gas reflects the nature and quality of the reservoirs. As examples, the seeps in the Transylvanian Basin reveal the quality of the microbial gas in the reservoirs, extremely rich in methane ( $>90 \mathrm{vol} \%$ ), without undesirable gases (e.g., $\mathrm{CO}_{2}, \mathrm{H}_{2} \mathrm{~S}$ ), while some seeps from the Eastern Carpathians release gas with indications of biodegradation, which may reflect shallow reservoirs of low quality petroleum. The intensity of seepage is also suggestive for the fluid pressure in the reservoirs, thus indicating the potential for their economic recovery. Basically, seeps are "natural sampling valves" of subsurface hydrocarbon accumulations. In this respect, HYSED-RO can be a valuable tool for petroleum exploration. The seep inventory shows the areas where natural hydrocarbon degassing is occurring, especially for small or ephemeral seeps (e.g., many small mud volcanoes in Transylvania or in the Moldavian Platform), often not known by national authorities for environmental protection and oil industry. Knowing the pre-existence of natural gas seepage —independent of man-made activity—is a critical prerequisite for baseline characterization needed to assess the environmental impacts due to petroleum exploitation, including shale fracking.

Finally, the inventory can also be useful for civil protection purposes, as some gas seeps may represent hazards for the population, infrastructure, and the built environment. The availability of 
relevant data on the occurrence of seeps may support the establishment of proper protective measures. This inventory also provides first data for estimating the greenhouse gas emission from geological sources at a national level [44].

The interactive map of HYSED-RO inventory is available at http:/ / www.hysedro.blogspot.com. The database files including data points and metadata are available for scientific use upon request to the corresponding author. This way of dissemination should be perceived as an open invitation to researchers from different fields of the natural sciences to contribute with information on the gas-emitting features they may observe during their field work, but the same invitation is extended to hikers, local communities, and the general public. This kind of voluntary contribution may help us to continuously update the database, and to monitor the evolution of some of the seeps. It will also support the better knowledge and protection of these natural features. A similar database is being developed for seeps in Italy (HYSED-IT; [62]), another European country with widespread hydrocarbon seepage.

Acknowledgments: This work was financially supported by the Romanian National Research Council through the Project PN-II-ID-PCE-2011-3-0537. The authors thank the editors and three anonymous reviewers for their constructive comments and suggestions.

Author Contributions: Field investigations and measurements were performed by Artur Ionescu, Calin Baciu, Giuseppe Etiope and Boglarka-Mercedesz Kis. The seep database was designed by Artur Ionescu, Pierfrancesco Burrato and Giuseppe Etiope. All the authors have contributed to writing the article.

Conflicts of Interest: The authors declare no conflict of interest. The founding sponsors had no role in the design of the study; in the collection, analyses, or interpretation of data; in the writing of the manuscript, and in the decision to publish the results.

\section{References}

1. Link, W.K. Significance of oil and gas seeps in world oil exploration. Am. Assoc. Pet. Geol. Bull. 1952, 36, 1505-1540.

2. Macgregor, D.S. Relationships between seepage, tectonics and subsurface petroleum reserves. Mar. Pet. Geol. 1993, 10, 606-619. [CrossRef]

3. Etiope, G. Natural Gas Seepage: The Earth's Hydrocarbon Degassing; Springer International Publishing: New York, NY, USA, 2015; p. 199.

4. Abrams, M.A. Significance of hydrocarbon seepage relative to petroleum generation and entrapment. Mar. Pet. Geol. 2005, 22, 457-477. [CrossRef]

5. Etiope, G.; Lassey, K.R.; Klusman, R.W.; Boschi, E. Reappraisal of the fossil methane budget and related emission from geologic sources. Geophys. Res. Lett. 2008, 35, L09307. [CrossRef]

6. Etiope, G.; Feyzullayev, A.; Baciu, C.L. Terrestrial methane seeps and mud volcanoes: A global perspective of gas origin. Mar. Pet. Geol. 2009, 26, 333-344. [CrossRef]

7. Etiope, G.; Feyzullayev, A.; Milkov, A.V.; Waseda, A.; Mizobe, K.; Sun, C.H. Evidence of subsurface anaerobic biodegradation of hydrocarbons and potential secondary methanogenesis in terrestrial mud volcanoes. Mar. Pet. Geol. 2009, 26, 1692-1703. [CrossRef]

8. Etiope, G.; Ciccioli, P. Earth's degassing-A missing ethane and propane source. Science 2009, $323,478$. [CrossRef] [PubMed]

9. Kopf, A.J. Significance of mud volcanism. Rev. Geophys. 2002, 40, 1005. [CrossRef]

10. Dimitrov, L.I. Mud volcanoes-The most important pathway for degassing deeply buried sediments. Earth Sci. Rev. 2002, 59, 49-76. [CrossRef]

11. Mazzini, A.; Etiope, G. Mud volcanism: An updated review. Earth Sci. Rev. 2017, 168, 81-112. [CrossRef]

12. Etiope, G.; Klusman, R.W. Microseepage in drylands: Flux and implications in the global atmospheric source/sink budget of methane. Glob. Planet. Chang. 2010, 72, 265-274. [CrossRef]

13. BP. BP Statistical Review of World Energy, 65th ed.; BP: London, UK, 2016; Available online: https://www.bp.com/content/dam/bp/pdf/energy-economics/statistical-review-2016/bp-statisticalreview-of-world-energy-2016-full-report.pdf (accessed on 12 April 2017).

14. Popescu, B.M. Romania's petroleum systems and their remaining potential. Pet. Geosci. 1995, 1, $337-350$. [CrossRef] 
15. Paraschiv, D. On the natural degasification of the hydrocarbon-bearing deposits in Romania. An. Inst. Geol. Geofiz. 1984, LXIV, 215-220.

16. Ionescu, A. Geogenic Methane in Petroliferous and Geothermal Areas in Romania: Origin and Emission to the Atmosphere. Ph.D. Thesis, Babes-Bolyai University Cluj-Napoca, Cluj-Napoca, Romania, 2015; p. 169.

17. CGG. Organic Geochemistry Data from FRogi and the Fluid Features Database. Available online: http:/ / robertson.cgg.com/products/frogi (accessed on 9 December 2015).

18. Wanek, F. Asvanyvizkutatas es szenhidrogenek a Keleti-Karpatokban 1908 elott. Koolaj es Foldgaz 2000, 33, 7-8. (In Hungarian)

19. Wanek, F. Az erdelyi foldgaz felfedezesenek igazi tortenete. Muszaki Szemle (Historia Scientarium 2) 2005, 30, 27-40. (In Hungarian)

20. Andrae, C.J. Salzen von Reussen bei Hermannstadt und über die geol. Bescchaff Enheit des Berges Büdös und Seiner Umgebung. Jahrbuch der k.k. geologischen Reichsanstalt 1853, 169-170. (In German)

21. Filtsch, J. Chemical analysis of the waters from the mud pools of Reussen. Verhandlungen und Mittheilungen des Siebenburgischen Vereins fur Naturwissenschaften zu Hermannstadt 1882, XXXII, 158-164. (In German)

22. Schuster, M. The mud-mounds and springs near the ponds in Reussen. Verhandlungen und Mittheilungen des Siebenbürgischen Vereins für Naturwissenschaften zu Hermannstadt 1882, XXXII, 158-164. (In German)

23. Oebeke, C.; Blanckenhorn, M. Report of a reconnaissance geological survey in Transylvania, in the fall of 1899, II. Petroleum and natural gas in the inner basin of Transylvania. Verhandlungen und Mittheilungen des Siebenburgischen Vereins fur Naturwissenschaften zu Hermannstadt 1901, L, 20-31. (In German)

24. Posewitz, T. Petroleum and asphalt in Hungary. Magyar Kiralyi Foldtani Intezet Evkonyve 1906, XV, $209-444$. (In Hungarian)

25. Simionescu, I. Contributii la geologia Moldovei dintre Siret si Prut (Contributions to the geology of Moldova between Siret and Prut rivers). Acad. Rom. Publ. Fond. "V. Adamachi" 1903, IX, 73-119. (In Romanian)

26. Enculescu, P. Cateva gloduri din Podisul Moldovei (Some "muds" from the Moldavian Plateau). Dari de Seama Inst. Geol. Rom. 1911, II, 133-145.

27. Vancea, A. Observatiuni geologice in regiunea de SW a Campiei Ardelene-Cu o privire generala asupra geologiei Basinului Transilvaniei si cu descrierea speciala a domului de gaz natural de la Zaul de Campie (Moinesti). Ph.D. Thesis part 1, Cluj University, Medias, Romania, 1929.; p. 67.

28. Vancea, A.I. Zacaminte de hidrocarbure naturale-Raspandirea geografica si conditiunile lor de zacamant II. Apele fosile-Importanţa compozitiei lor chimice in studiul zacamintelor de hidrocarbure naturale. Ph.D. Thesis part 2, Cluj University, Medias, Romania, 1929; p. 25.

29. Banyai, J. Udvarhely Varmegye Iszapforrasai; Erdelyi Muzeum: Cluj-Napoca, Romania, 1932; Volume 1-3, pp. 1-17. (In Hungarian)

30. Ciocardel, R. Regiunea petrolifera Berca-Beciu-Arbanasi. Studii Tehn. Econ. 1949, A/4, 32. (In Romanian)

31. Ciupagea, D.; Pauca, M.; Ichim, T. Geologia Depresiunii Transilvaniei; Academiei, R.S.R.: Bucharest, Romania, 1970; p. 256. (In Romanian)

32. Peaha, M. Vulcanii noroiosi din Romania. Studii si cercetari de geologie, geofizica, geografie, Seria Geografie. 1965, 12. (In Romanian)

33. Filipescu, M.N.; Huma, I. Geochimia Gazelor Naturale; Editura Academiei Republicii Socialiste Romania: Bucharest, Romania, 1979; p. 175. (In Romanian)

34. Baciu, C.; Etiope, G. The Environmental Significance of Methane Emission from Geogenic Sources. Univ. Babes Bolyai Geol. 2002, 1, 31-36.

35. Etiope, G.; Baciu, C.; Caracausi, A.; Italiano, F.; Cosma, C. Gas flux to the atmosphere from mud volcanoes in eastern Romania. Terra Nova 2004, 16, 179-184. [CrossRef]

36. Baciu, C.; Caracausi, A.; Etiope, G.; Italiano, F. Mud volcanoes and methane seeps in Romania: Main features and gas flux. Ann. Geophys. 2007, 50, 501-511.

37. Baciu, C.; Etiope, G.; Cuna, S.; Spulber, L. Methane seepage in an urban development area (Bacau, Romania): Origin, extent and hazard. Geofluids 2008, 8, 311-320. [CrossRef]

38. Spulber, L.; Etiope, G.; Baciu, C.; Malos, C.; Vlad, S.N. Methane emissions from natural gas seeps and mud volcanoes in Transylvania (Romania). Geofluids 2010, 10, 463-475. [CrossRef]

39. Etiope, G.; Baciu, C.; Schoell, M. Extreme methane deuterium, nitrogen and helium enrichment in natural gas from the Homorod seep (Romania). Chem. Geol. 2011, 280, 89-96. [CrossRef] 
40. Pop, C.I. Emisii geogene de metan in Platforma Moldoveneasca si Bazinul Transilvaniei. Ph.D. Thesis, Babes-Bolyai University, Cluj-Napoca, Romania, 2014.

41. Frunzeti, N.; Baciu, C.; Etiope, G.; Pfanz, H. Geogenic emission of methane and carbon dioxide at Beciu mud volcano (Berca-Arbanasi hydrocarbon-bearing structure, Eastern Carpathians, Romania). Carpath. J. Earth Environ. Sci. 2012, 7, 159-166.

42. Pop, C.I.; Ionescu, A.; Baciu, C. Methane seepage from geologic sources on the Moldavian Platform (Eastern Romania). Carpath. J. Earth Environ. Sci. 2015, 10, 203-210.

43. Rowland, H.A.L.; Omoregie, E.O.; Millot, R.; Jimenez, C.; Mertens, J.; Baciu, C.; Hug, S.J.; Berg, M. Geochemistry and arsenic behaviour in groundwater resources of the Pannonian Basin (Hungary and Romania). Appl. Geochem. 2011, 26, 1-17. [CrossRef]

44. Baciu, C.; Ionescu, A.; Etiope, G. Hydrocarbon seeps in Romania: Natural gas origin and release to the atmosphere. Mar. Pet. Geol. 2017, under review.

45. Geological Institute. Geological Map of Romania, 1:1,000,000; Geological Institute of Romania: Bucharest, Romania, 1967.

46. Pawlewicz, M.J.; Steinshouer, D.W.; Gautier, D.L. Map Showing Geology, Oil and Gas Fields, and Geologic Provinces of Europe including Turkey; Open file report 97-470I; USGS: Reston, VA, USA, 2002.

47. Demetrescu, C.; Andreescu, M. On the thermal regime of some tectonic units in a continental collision environment in Romania. Tectonophysics 1994, 230, 265-276. [CrossRef]

48. Sandulescu, M. Geotectonica Romaniei (Geotectonics of Romania); Ed. Tehnica: Bucharest, Romania, $1984 ;$ p. 336.

49. Mutihac, V.; Stratulat, M.L.; Fechet, R.M. Geologia Romaniei (Geology of Romania); Editura Didactică şi Pedagogică: Bucureşti, Romania, 2004.

50. Demetrescu, C. Thermal structure of the crust and upper mantle of Romania. Tectonophysics 1982, 90, 123-135. [CrossRef]

51. Demetrescu, C.; Polonic, G. The evolution of the Pannonian Depression (Romanian sector) as derived from subsidence and heat flow data. Tectonophysics 1989, 164, 287-299. [CrossRef]

52. Andreescu, M.; Burst, D.; Demetrescu, C.; Ene, M.; Polonic, G. On the geothermal regime of the Moesian Platform and Getic Depresion. Tectonophysics 1989, 164, 281-286. [CrossRef]

53. Bonini, M.; Mazzarini, F. Mud volcanoes as potential indicators of regional stress and pressurized layer depth. Tectonophysics 2010, 494, 32-47. [CrossRef]

54. Krézsek, C.S.; Bally, A.W. The Transylvanian Basin (Romania) and its relation to the Carpathian fold and thrust belt: Insights in gravitational salt tectonics. Mar. Pet. Geol. 2006, 23, 405-442. [CrossRef]

55. Baciu, C.; Etiope, G. Mud volcanoes and seismicity in Romania. In Mud volcanoes. Geodynamics and Seismicity, NATO Science Series, IV Earth and Environmental Sciences; Martinelli, G., Panahi, B., Eds.; Springer: Berlin, Germany, 2005; pp. 77-87.

56. Murgeanu, G.; Dumitrescu, I.; Mirauta, O.; Sandulescu, M.; Stefanescu, M.; Bandrabur, T. Geological Map of Romania 1:200,000; Geological Institute of Romania: Bacau, Romania, 1970.

57. Ionescu, A.; Baciu, C.; Kis, B.-M.; Sauer, P.E. Evaluation of Dissolved Light Hydrocarbons in Different Geological Settings in Romania. Chem. Geol. Available online: http:/ / doi.org/10.1016/j.chemgeo.2017.04.017 (accessed on 10 May 2017). [CrossRef]

58. Hunt, J.M. Petroleum Geochemistry and Geology; W.H. Freeman and Co.: New York, NY, USA, 1996; p. 743.

59. Pollack, H.N.; Hurter, S.J.; Johnson, J.R. Heat flow from the Earth's interior: Analysis of the global data set. Rev. Geophys. 1993, 31, 267-280. [CrossRef]

60. Italiano, F.; Kis, B.M.; Baciu, C.; Ionescu, A.; Harangi, S.Z.; Palcsu, L. Geochemistry of dissolved gases from the Eastern-Carpathians-Transylvanian Basin boundary. Chem. Geol. 2016. [CrossRef]

61. Schwietzke, S.; Sherwood, O.A.; Bruhwiler, L.M.P.; Miller, J.B.; Etiope, G.; Dlugokencky, E.J.; Michel, S.E.; Arling, V.A.; Vaughn, B.H.; White, J.W.C.; et al. Upward revision of global fossil fuel methane emissions based on isotope database. Nature 2016, 538, 88-91. [CrossRef] [PubMed]

62. Burrato, P.; Etiope, G.; Vannoli, P.; Ionescu, A. Inventory of hydrocarbon seeps in Italy (HYSED-IT). (In preparation)

(C) 2017 by the authors. Licensee MDPI, Basel, Switzerland. This article is an open access article distributed under the terms and conditions of the Creative Commons Attribution (CC BY) license (http:/ / creativecommons.org/licenses/by/4.0/). 